\title{
Too much or too little work? Couples' actual and preferred employment patterns and work hours mismatches in Europe
}

\section{$\mathrm{Zu}$ viele oder zu wenige Arbeitsstunden? Haushaltserwerbsmuster und Arbeitszeitpräferenzen von Paaren in Europa}

\begin{abstract}
:
The most widely cited European data on work hours mismatches at the couple level date back to the 1990s. The general gist of analyses of these data was that 'overworked' dual-earner couples frequently preferred work hours reductions, especially those with childcare responsibilities. This study uses more recent data from the European Social Survey (2010-12) to update the available evidence on actual and preferred breadwinner models and on the occurrence and determinants of work hours mismatches among couples in Europe. The focus is on differences between demographic groups and countries in the degree to which cohabiting couples are either underemployed (working fewer hours than desired) or overemployed (working more hours than desired). Our analyses show that about one third of couples are underemployed, while only one in ten report being overemployed. We identify low education and the presence of children below school age as risk factors for underemployment, whereas highly educated women and fathers of teenagers tend to be overemployed. In a comparison of 16 European countries, we find couples in Greece, Ireland, Slovenia, and Spain to be most at risk of experiencing underemployment - in the countries that were most strongly affected by the recession. The effects of children on the experience of hours mismatches are found to vary across Europe - a particularly strong association of children below school age with parental underemployment is observed in Central and Eastern Europe, Finland,
\end{abstract}

\section{Zusammenfassung:}

Die letzte große Erhebung und Analyse von Umfragedaten $\mathrm{zu}$ den Arbeitszeitpräferenzen von Paaren in Europa wurde in den 1990er Jahren durchgeführt. Der Tenor dieser Analysen war, dass sich die oft ,überarbeiteten' ZweiverdienerPaare in vielen Fällen eine Reduktion ihrer Arbeitszeit wünschen, vor allem bei Vorliegen von Kinderbetreuungspflichten. Die vorliegende Studie nützt jüngere Daten aus dem European Social Survey (2010-12). Der Fokus der Analyse liegt auf Unterschieden zwischen demographischen Gruppen und Ländern im Ausmaß zu dem Paare mehr oder weniger Stunden erwerbstätig sind als dies ihren Präferenzen entspricht (Über- bzw. Unterbeschäftigung). Die Analysen zeigen, dass rund ein Drittel der Paare unterbeschäftigt ist (Präferenz für Arbeitszeitaufstockung), während nur rund eines von zehn Paaren angibt, überbeschäftigt zu sein (Präferenz für Arbeitszeitreduktion). Als Risikofaktoren für Unterbeschäftigung werden niedrige Bildung und Kinder im Vorschulalter sowie auf der Länderebene hohe Arbeitslosigkeit (Griechenland, Irland, Slowenien, Spanien) identifiziert. Höher gebildete Frauen bzw. Paare mit älteren Kindern sind dagegen mit einer höheren Wahrscheinlichkeit überbeschäftigt. Der Effekt von kleinen Kindern auf das Risiko von Unterbeschäftigung variiert ja nach Land. Stärkere Effekte werden in Zentral- und Osteuropa, Finnland und Deutschland beobachtet, vergleichsweises geringe oder keine Effekte in Großbritannien, Griechenland, Irland und Schweden. 
and Germany and a particularly weak one in Great Britain, Greece, Ireland, and Sweden.

Key words: couples, labour supply, preferences, hours mismatch, European Social Survey
Schlagwörter: Paare, Beschäftigung, Arbeitszeitpräferenzen, Unterbeschäftigung, European Social Survey

\section{Introduction}

While some workers work part-time involuntarily, others are putting in more time at work than they would prefer. The occurrence of work hours mismatches of these two kinds underemployment and overemployment - is a well-documented phenomenon that points to the fact that observable employment behaviours (such as actual hours of work) are the result of constrained choices (e.g., Altonji/Paxson 1988; Böheim/Taylor 2004; Otterbach 2010). Employers typically offer a very limited number of wage-hours combinations and therefore employees may not be able to work their preferred number of hours. Moreover, not all wage-hours combinations are compatible with breadwinning responsibilities on the one hand (i.e., need to earn a certain income) and time constraints, on the other hand. Constraints on working hours may derive from employers as well as from outside the workplace such as from care responsibilities.

Prevalent work hours mismatches are cause for concern and call for policy intervention, since it has been shown that the experience of such mismatches is associated with poor mental well-being (Wooden et al. 2009; De Moortel et al. 2017) and self-rated health (Bell et al. 2012). Negative associations with well-being outcomes have been found for both types of mismatch and there is evidence suggesting that underemployment may have a stronger negative effect on mental well-being (Wunder/Heineck 2013), whereas overemployment shows a stronger association with poor self-rated health (Bell et al. 2012). Underemployment, which may be conceptualised as an employment outcome that is halfway between adequate employment and unemployment (Dooley 2003) has furthermore been shown to be associated with a greater risk of financial hardship (Warren 2015). In summary, hours mismatches have negative implications for the well-being and economic welfare of individuals. In fact, hours mismatches have been shown to be as good a predictor of well-being outcomes as the number of hours worked (Wooden 2009; Bassanini/Caroli 2015). In addition to the negative implications of hours mismatches for the health and well-being of the workers concerned, such mismatches have undesirable societal consequences such as an inefficient allocation of labour (e.g., underutilisation in the case of underemployment, see Wilkins/Wooden 2001) and a bi-furcation of working time with an exhausted core workforce working longer hours than desired and an underemployed peripheral workforce (Jacobs/Green 1998). Negative ramifications of hours mismatches have also been found for the performance of organisations, with lower levels of organisational commitment among mismatched workers (overview in Reynolds/Aletraris 2006: 619).

Given the high degree of educational homogamy within couples (Blossfeld/Timm 2003; Schwartz/Mare 2005) and the associated working time polarisation between higher 
educated dual-career couples and lower educated couples with two partners at risk of underemployment (Konietzka/Kreyenfeld 2010), it was argued that hours mismatches can be better understood at the couple level than the individual level (Clarkberg/Moen 2001). This conforms to the idea that the choice of working hours is often not an individual matter - working hours are negotiated not only with employers but also with partners (Reynolds 2014).

Given the evidence on negative individual, organizational, and societal consequences of hours mismatches, and since the last available evidence on work hours mismatches among couples in Europe dates back to the 1990s (see literature review, below), the aim of the present study is to provide new empirical evidence for the incidence and distribution of work hours mismatches among couples in Europe. A specific focus of the study is on the provision of rich descriptive information on cross-country differences in actual and preferred employment patterns at the couple level (breadwinner models) and the prevalence of work hours mismatches. Moreover, using regression analysis, we investigate the impact of education and the family life-cycle (defined by the presence and age of children) on a couple's risk of experiencing over- or underemployment in different European countries. We use data from the European Social Survey that was collected between 2010 and 2012, thus mapping a period when large parts of Europe were still suffering from recession and high unemployment.

\section{Literature review}

The early literature on work hours mismatches had a clear focus on the issue of overemployment. In the late 1990 s and early 2000 s, a considerable body of research emerged, shifting the focus from individual workers to couples and families. This literature emphasised the issue of 'overworked families' who would like to reduce their working hours in order to achieve a better work-family fit (Clarkberg/Moen 2001; Jacobs/Gerson 2001; Jacobs/Green 1998; Moen/Dempster-McClain 1987). It was argued that many couples work more hours than they would prefer and that such mismatches were in the main tied to the aim of combining paid work with childcare responsibilities (Merz 2002; Clarkberg/Moen 2001).

The most widely cited comparative European data on working time preferences at the couple level date back to the 1990s. The European Foundation for the Improvement of Working and Living Conditions in Europe carried out the 'Employment Options of the Future' (EOF) survey in the member states of the European Union in 1998 and Norway. Respondents were asked to state the hours that they would like to work themselves, and the hours that they would like their partner to work, if they had a free choice, but taking into account the need to earn a living. Calculations based on these micro-data have been widely published (Bielenski et al. 2002; Väisänen/Nätti 2002; Fagan/Warren 2001; OECD 2001: 136). The general gist of the analyses was that the preferences of couples were in many cases not in line with their behaviours and that dual-earner couples frequently preferred work hours reductions (Väisänen/Nätti 2002), especially in the presence of small children (OECD 2001: 136; see also Lewis et al. 2008: 30). 
The more recent literature has put the issue of underemployment to the fore. Data from the 2005 International Social Survey Programme (ISSP) ${ }^{1}$ shows that the share of workers who preferred to increase their working hours and earn more money (underemployed) exceeded the share of workers who preferred to reduce their hours while earning less (overemployed) - especially in countries with high unemployment rates (Otterbach 2010). Corroborating evidence from labour force survey data shows that during the recession following the financial crisis that started in 2007/08, the shares of involuntary parttime workers, who prefer full-time jobs, increased in a number of European countries, rendering many part-timers underemployed (Rubery/Rafferty 2013; Horemans et al. 2016). Given that involuntary part-timers are more at risk of poverty than voluntary parttimers, surging underemployment in the form of involuntary part-time work has attained a higher priority on the policy agenda of many countries (Horemans et al. 2016). Labour force survey data on underemployment are not easy to interpret, however, as only those part-timers who state to be looking for a full-time job are defined as underemployed, whereas those who work part-time because of caring activities are defined as voluntary part-timers (OECD 2010).

Regarding the distribution of hours mismatches, previous research suggests that men and highly skilled individuals tend to be more at risk of involuntarily working long hours, whereas women and the low skilled are more at risk of involuntarily working short hours (Stier/Lewin-Epstein 2003; van Echtelt et al. 2006; Sousa-Poza/Henneberger 2002). The evidence on the impact of children is mixed. For the United States, Reynolds (2003) finds that workers with young children are not more likely to face an hours mismatch than childless workers. A number of further studies conclude that children are not strongly connected to the risk of hours mismatches (for overview, Reynolds and Johnson 2012). For Australia, Wilkins (2006) finds the risk of parental underemployment to increase in the number of dependent children. Whereas for men the risk increases with the age of the youngest child, for women the risk decreases when the youngest child is a teenager. Reynolds and Aletraris (2006), by contrast, find that Australian mothers of teenagers are more likely to be underemployed than those with younger children. Using longitudinal data, Reynolds and Johnson (2012) present evidence that in the United States the transition from being childless to having one child increases both parents' risk of overemployment. However, the authors conclude that the effect is small compared to work-related transitions (i.e., changes in terms of job characteristics). To the best of our knowledge, to date, no study has assessed differences between countries in the impact of children on the risk of work hours mismatches.

\section{Theory and hypotheses}

A central determinant of employment behaviours is education. In classic human capital theory, the better educated are more likely to seek employment due to their higher wage

1 Data on working time preferences were collected as part of the ISSP in 1997 and 2005 and the second round of the ESS, but only at the individual level. These data do hence not allow for couplelevel analysis. 
potential, in other words because their opportunity costs of not having a job are higher (Becker 1991). Another reason why the better educated are more likely to prefer a stronger involvement in the labour market is because they tend to have access to jobs that provide greater intrinsic rewards (Gerson 1985; Steiber et al. 2016). From the perspective of opportunity cost theory, we may thus expect the better educated to prefer employment to non-employment and to work a higher number of weekly hours than the lower educated. Due to the pronounced educational homogamy of couples in Europe (Blossfeld/Timm 2003), these individual-level predictions of education effects on preferred labour supply, can be applied to the couple level (Steiber et al. 2016). While low educated couples may have low economic and non-economic opportunity costs of not working (i.e., low potential job quality), in many countries they may still prefer a strong labour market involvement of both the man and the woman, due to strong economic pressures on both partners to contribute to the household income (Haas et al. 2006). In summary, both high educated couples as well as low educated couples may prefer a strong involvement in the labour market, albeit for different reasons.

Whereas competing hypotheses can thus be formulated regarding the effects of education on couples' preferred hours, more straightforward predictions can be made regarding the impact of education on the occurrence of hours mismatches. In most countries, we observe large education-based differences in demand-side constraints. The low educated, in particular, face employment constraints, especially in times of slack demand (Erlinghagen 2008; Gesthuizen et al. 2011). Among low-educated couples, both partners may face a high risk of under- and unemployment (Konietzka/Kreyenfeld 2010). Overall, we would thus predict a higher incidence of wanting to work more hours than offered among lower compared to higher educated couples. Conversely, we expect higher levels of education to protect couples from underemployment.

However, the highly educated may experience a different type of constraint on their working hours: Skilled occupations are often only accessible for those willing to work long hours (Clarkberg/Moen 2001). Such constraints on working hours imposed by employers (i.e., 'lumpiness' of labour demand) may lead to mismatches between hours preferred and hours actually worked (Hamermesh/Pfann 1996). Moreover, jobs in skilled occupations may encourage incumbents to autonomously work longer hours than they prefer (van Echtelt et al. 2006). This 'new lumpiness' of labour (ibid.) may mostly affect those in jobs that afford a high degree of autonomy, carry responsibility, and allow for learning and self-development on the job. Such intrinsically rewarding jobs may be time-greedy with the result that highly motivated employees work longer hours than they would prefer based on mere financial considerations. In sum, both the 'traditional' and the 'new' lumpiness of labour may lead to higher risks of overemployment among highly educated couples compared to lower educated ones.

Also the presence of children is key to understanding couples' labour market behaviour. Whereas it is well-established that small children tend to suppress the amount of paid work carried out by mothers, especially in countries that fail to offer affordable public childcare (Steiber/Haas 2012; Pettit/Hook 2005), the impact of children on the risk of experiencing hours mismatches is theoretically ambivalent. The classic child-mismatch hypothesis suggests that the arrival of a child leads to a reduction of preferred working hours (among women in particular), yet such preferences for work hours reductions can- 
not always be realised (Reynolds/Johnson 2012) - for this reason, it is usually expected that parents tend to suffer from overemployment (Jacobs/Gerson 2004). This is in line with the concept of a 'lumpiness of labour' (Hamermesh/Pfann 1996), i.e., parents ending up working more hours than they prefer due to restrictions on available hours (employer constraints). Assuming that in the early family life-cycle, the demand for care time is greater than the demand for more money, whereas the demand for time declines and the demand for money increases when children grow older, we expect the risk of overemployment to decline with the age of the youngest child.

In contrast to the classic child-mismatch hypothesis that emphasises the risk of parental overemployment, care responsibilities may also increase the risk of underemployment when parents would prefer working longer hours (but only) under the condition that better non-parental childcare opportunities were available (Tsang et al. 2014). In other words, in the absence of adequate institutional care support parents and especially mothers may not be able to combine employment (in particular, a full-time job) with childcare responsibilities, yet they may nevertheless state a preference for an increase in working hours (Wilkins 2006). Under the assumption that institutional care becomes more accessible and affordable when children enter school, the risk of parental underemployment would be expected to decline when children grow older.

In this context, differences across countries may emerge. In contexts, where an adequate support for institutional care is lacking such as in Central and Eastern Europe (CEE), large parts of Continental Europe, Southern Europe, Great Britain and Ireland (see e.g., Saraceno/Keck 2010), the risk of parental underemployment is expected to be higher than in countries that offer affordable care services for smaller and older children (e.g., in Scandinavia and to some degree France and Belgium, Saraceno/Keck 2010). Another institutional factor that may support or undermine parents' capacity to reconcile having children with working the preferred number of hours is the availability of part-time work (Del Boca 2002). In parts of Europe (e.g., in CEE and Southern Europe), where parents only have the choice between working full-time and not being employed at all due to a lack of part-time jobs, we may expect the risk of parental hours mismatch (over- and underemployment) to be greater compared to countries that offer flexible part-time opportunities (e.g., in parts of Continental Europe such as in the Netherlands).

\section{Data and methods}

\section{Data and measures of work time}

In succession of the 1998 EOF Survey, new data on European couples' actual and preferred employment arrangements only became available with Round 5 of the European Social Survey (ESS), fielded in the years 2010-2012 ${ }^{2}$. The ESS collects international survey data from face-to-face interviews, drawing on random samples of between 1,500 and

2 In 11 countries, the survey was fielded in 2010/11, in Finland and Hungary field work was restricted to 2010, in Spain and Greece it was restricted to 2011, and in Ireland it extended to 2011/12. 
3,000 individuals aged 15 and over per country. Similar to the 1998 EOF Survey, in Round 5 respondents were asked 'How many hours a week, if any, would you choose to work, bearing in mind that your earnings would go up or down according to how many hours you work?' and 'If you could choose, how many hours a week, if any, would you like your partner to work bearing in mind that your partner's earnings would go up or down according to how many hours s/he works?'. Moreover, respondents were asked about their and their partner's current employment status and their usual number of weekly working hours (including any paid or unpaid overtime). Investigating the data, we find that the assumption that most respondents evaluate their partner's hours accurately is tenable. As shown in the appendix Table A1, the estimated average actual and preferred hours worked by the partner differ only slightly from the average actual and preferred (own) hours reported by respondents of the opposite sex.

Using the combined information about the female and the male partner's employment status, their actual and preferred working hours, we distinguish six employment arrangements: the male breadwinner model (MB, the man works full-time, the woman is not employed), the modernised male breadwinner model (MMB, the man works full-time, the woman part-time - also known as the one-and-a half-earner model), the dual breadwinner model (DB, both partners work full-time), the dual part-time model (DPT, both partners work part-time), the female breadwinner model ( $\mathrm{FB}$, the woman works full-time, the man part-time or not at all), and the no-breadwinner model (NB, both partners are not employed or only one of the partners works part-time). Following the OECD standard, parttime work is defined as working less than 30 hours per week. Comparing couples' actual with their preferred breadwinner models we distinguish (1) couples whose stated preferences match their behaviour (2) from underemployed couples, and (3) overemployed couples (see Table A2 in the appendix for coding frame).

In some prior studies (e.g., Väisänen/Nätti 2002) hours mismatches at the couplelevel were measured by simply subtracting the sum of couple's actual hours from the sum of their preferred hours (with negative values indicating underemployment and positive ones indicating overemployment). In this study, we decidedly take a different approach and define the couple's desire to change their current breadwinner arrangement as an indicator of mismatch. This is because only the categorical breadwinner approach takes a gendered perspective on couples' mismatch, whereas the metric mismatch measure that sums up partners' actual and preferred working hours potentially conflates one partner's overemployment with the other partner's underemployment. Couples living in a male breadwinner arrangement may for example prefer the man to work shorter full-time hours (minus 15 hours) and the woman to start a part-time job (plus 20 hours) - our categorical measure records the fact that in this exemplary couple a part-time job is lacking instead of (wrongly) classifying the couple as fairly well-matched.

\section{Sample}

The sample is restricted to individuals who cohabit with a partner of the opposite sex and who are between 20 and 64 years of age (both partners satisfy this age restriction). We use data from 16 countries (Belgium, Denmark, Estonia, Finland, France, Germany, Great Britain, Greece, Hungary, Ireland, the Netherlands, Norway, Slovenia, Spain, Sweden, 
and Switzerland), including only those countries that provide data with limited amounts of missing values for both actual and preferred employment arrangements.

\section{Analytical strategy}

The first aim of the study is to provide rich descriptive evidence on couples' actual and preferred employment arrangements in Europe (breadwinner models). To this end, we compare shares of couples living and preferring different breadwinner models in each of the countries analysed. This gives a first overview of the degree to which preferences and behaviours overlap (Table 1). To provide some insight into the types of breadwinner models that couples tend to be satisfied or dissatisfied with, we then cross-tabulate actual and preferred arrangements (Table 2).

The second aim is to identify the determinants of mismatch between couples' actual and preferred employment. To this end, we carry out regression analysis to investigate the socio-demographic risk factors for the occurrence of under- and overemployment. We estimate multinomial logistic regression models using the 3-category mismatch indicator described above as the dependent variable. The following main predictors enter the model: the level of education of each partner (low, medium, high) ${ }^{4}$ and couples' stage in an ideal-typical family life-cycle that differentiates between a) childless couples, b) couples whose youngest child is below age $6, \mathrm{c}$ ) whose youngest child is aged 6-11, d) whose youngest child is aged $12<18$, e) whose youngest child has reached age 18 and still lives in the household, or f) whose youngest child has left the household (empty nest). Standard control variables include the age of the male and female partner and residence in rural or urban settings. ${ }^{5}$ Moreover, in order to detect and account for potential gender differences in the reporting of mismatch, we control for whether the information on the couple's preferred and actual employment was reported by the male or female part of the couple. First, we estimate a country fixed effects model based on a pooled sample of women and men from 16 countries. The results are reported as marginal effects (Table 3). Second, to test the assumption that women and men as part of couples report in a similar way on the impact of children on hours mismatches, we run separate models for women and men (Figure 1). Finally, to investigate differences between countries in terms of the impact of children on the occurrence of hours mismatches we run a separate model for each of the 16 countries (Figure 2). Due to the restricted number of countries analysed, we cannot use

3 We consider only countries that provide less than $10 \%$ missing values for actual and preferred arrangements. Missing values for actual and preferred arrangements, respectively, were: Belgium $(1.6 \% ; 5.7 \%)$, Switzerland $(1.7 \% ; 8.7 \%)$, Germany $(0.7 \% ; 4.2 \%)$, Denmark $(0.5 \% ; 3.4 \%)$, Estonia $(1.9 \% ; 7.2 \%)$, Spain $(0.6 \% ; 4.9 \%)$, Finland $(1.0 \% ; 1.6 \%)$, France $(1.1 \% ; 4.9 \%)$, Britain $(1.6 \%$; $9.9 \%)$, Greece $(1.8 \% ; 7.7 \%)$, Hungary $(2.6 \% ; 10.7 \%)$, Ireland $(0.2 \% ; 1.4 \%)$, Netherlands $(0.7 \%$; $7.7 \%)$, Norway $(0.1 \% ; 1.2 \%)$, Sweden $(0.6 \% ; 2.6 \%)$, Slovenia $(2.4 \% ; 4.5 \%)$.

4 Low education includes less than primary, primary, and lower secondary education (attainment below the general ISCED 3 level). Medium education is defined as upper secondary education (ISCED 3 ), and high education is defined as post-secondary or tertiary education (ISCED 4-6).

5 The variable distinguishes couples living in 1) a country village, a farm or home in the countryside, 2) a town or a small city, and 3) a big city or the outskirts/suburbs of a big city. It shall control for differences in job opportunities between urban and rural areas. 
multilevel modelling to directly model effects of country-level factors on the occurrence and distribution of mismatch. Instead, we aimed to follow a stratified approach and started by grouping the countries analysed along the lines of existing typologies of welfare state regimes and family policy configurations (e.g., Gornick/Meyers 2003; Saraceno/ Keck 2010). Yet, the analyses of country-specific patterns regarding child effects revealed a high degree of heterogeneity within groups of countries typically clustered together (Figure 2). For this reason, our analytical strategy is to carry out a country-by-country analysis, the results of which are then interpreted in the light of the literature on relevant contextual conditions (e.g., childcare infrastructure, availability of part-time jobs). Given the limited sample sizes at the country level, especially in some of the stages of the family life-cycle, we employ a coarsened family life-cycle variable in the country-by-country analysis that pools parents with school-age children. The analytical contrast focused upon in this part of the analysis is the mismatch experienced by parents whose youngest child is aged below 6 compared to parents whose youngest child is aged 6 to 17 .

\section{Results}

\section{Actual and preferred employment arrangements}

The comparison of couples' actual and preferred breadwinner models shows that underemployment is fairly wide-spread in Europe (Table 1). In 13 out of the 16 countries investigated, a larger share of couples prefer a dual breadwinner model than practise it (exceptions are Britain, the Netherlands, and Switzerland). The gap between the shares of couples preferring and living dual breadwinner models is largest in Greece (42\%-points), followed by Slovenia (30), Hungary, (25), Spain, and Finland (24). Also single-earner arrangements are found to be largely involuntary. In all countries, less than $15 \%$ of couples prefer the male breadwinner model and $5 \%$ or less prefer the female breadwinner model (Table 1). Cross-tabulating actual and preferred models (Table 2), we find that in all countries, less than a third of male breadwinner couples actually prefer this arrangement (less than 10\% in Norway, Slovenia, and Sweden). 
Table 1: Actual and preferred couple employment arrangements, 2010-2012

\begin{tabular}{|c|c|c|c|c|c|c|c|c|}
\hline & DB & MMB & MB & DPT & NB & FB & Total & $\mathbf{N}$ \\
\hline \multicolumn{9}{|c|}{ Great Britain } \\
\hline Actual & $37.9 \%$ & $22.6 \%$ & $20.7 \%$ & $2.1 \%$ & $10.9 \%$ & $5.8 \%$ & $100 \%$ & 838 \\
\hline Preferred & $34.9 \%$ & $34.1 \%$ & $9.9 \%$ & $12.3 \%$ & $6.6 \%$ & $2.3 \%$ & $100 \%$ & 838 \\
\hline \multicolumn{9}{|c|}{ Netherlands } \\
\hline Actual & $28.2 \%$ & $37.3 \%$ & $17.9 \%$ & $1.6 \%$ & $9.7 \%$ & $5.4 \%$ & $100 \%$ & 787 \\
\hline Preferred & $25.8 \%$ & $45.1 \%$ & $8.2 \%$ & $7.6 \%$ & $10.2 \%$ & $3.1 \%$ & $100 \%$ & 787 \\
\hline \multicolumn{9}{|c|}{ Switzerland } \\
\hline Actual & $32.6 \%$ & $31.6 \%$ & $24.9 \%$ & $1.1 \%$ & $5.3 \%$ & $4.5 \%$ & $100 \%$ & 623 \\
\hline Preferred & $31.5 \%$ & $46.7 \%$ & $11.1 \%$ & $6.1 \%$ & $3.4 \%$ & $1.3 \%$ & $100 \%$ & 623 \\
\hline \multicolumn{9}{|l|}{ Belgium } \\
\hline Actual & $43.5 \%$ & $17.2 \%$ & $16.4 \%$ & $0.8 \%$ & $15.6 \%$ & $6.6 \%$ & $100 \%$ & 757 \\
\hline Preferred & $49.9 \%$ & $31.2 \%$ & $6.7 \%$ & $6.5 \%$ & $3.3 \%$ & $2.4 \%$ & $100 \%$ & 757 \\
\hline \multicolumn{9}{|l|}{ France } \\
\hline Actual & $51.0 \%$ & $10.0 \%$ & $16.9 \%$ & $0.5 \%$ & $12.4 \%$ & $9.2 \%$ & $100 \%$ & 672 \\
\hline Preferred & $67.9 \%$ & $15.8 \%$ & $4.2 \%$ & $3.5 \%$ & $5.3 \%$ & $3.3 \%$ & $100 \%$ & 672 \\
\hline \multicolumn{9}{|l|}{ Germany } \\
\hline Actual & $33.0 \%$ & $27.0 \%$ & $22.1 \%$ & $1.3 \%$ & $10.9 \%$ & $5.7 \%$ & $100 \%$ & 1287 \\
\hline Preferred & $42.2 \%$ & $36.2 \%$ & $6.6 \%$ & $6.4 \%$ & $6.6 \%$ & $2.2 \%$ & $100 \%$ & 1287 \\
\hline \multicolumn{9}{|l|}{ Denmark } \\
\hline Actual & $62.6 \%$ & $8.5 \%$ & $12.2 \%$ & $1.1 \%$ & $8.2 \%$ & $7.4 \%$ & $100 \%$ & 729 \\
\hline Preferred & $70.9 \%$ & $12.9 \%$ & $2.3 \%$ & $4.3 \%$ & $5.2 \%$ & $4.4 \%$ & $100 \%$ & 729 \\
\hline \multicolumn{9}{|l|}{ Finland } \\
\hline Actual & $54.7 \%$ & $5.1 \%$ & $17.7 \%$ & $0.9 \%$ & $10.7 \%$ & $11.0 \%$ & $100 \%$ & 810 \\
\hline Preferred & $78.4 \%$ & $7.2 \%$ & $3.3 \%$ & $4.4 \%$ & $3.1 \%$ & $3.6 \%$ & $100 \%$ & 810 \\
\hline \multicolumn{9}{|l|}{ Sweden } \\
\hline Actual & $67.1 \%$ & $9.6 \%$ & $11.2 \%$ & $0.8 \%$ & $4.6 \%$ & $6.8 \%$ & $100 \%$ & 636 \\
\hline Preferred & $82.7 \%$ & $8.0 \%$ & $1.3 \%$ & $3.5 \%$ & $1.9 \%$ & $2.7 \%$ & $100 \%$ & 636 \\
\hline \multicolumn{9}{|l|}{ Norway } \\
\hline Actual & $55.5 \%$ & $15.4 \%$ & $12.8 \%$ & $1.2 \%$ & $8.1 \%$ & $7.0 \%$ & $100 \%$ & 770 \\
\hline Preferred & $75.7 \%$ & $15.7 \%$ & $1.6 \%$ & $2.7 \%$ & $1.1 \%$ & $3.2 \%$ & $100 \%$ & 770 \\
\hline \multicolumn{9}{|l|}{ Estonia } \\
\hline Actual & $49.9 \%$ & $5.4 \%$ & $27.1 \%$ & $0.3 \%$ & $8.2 \%$ & $9.2 \%$ & $100 \%$ & 672 \\
\hline Preferred & $68.9 \%$ & $7.9 \%$ & $6.1 \%$ & $3.6 \%$ & $11.3 \%$ & $2.2 \%$ & $100 \%$ & 672 \\
\hline \multicolumn{9}{|l|}{ Greece } \\
\hline Actual & $27.9 \%$ & $4.6 \%$ & $38.6 \%$ & $0.9 \%$ & $20.1 \%$ & $7.8 \%$ & $100 \%$ & 980 \\
\hline Preferred & $69.4 \%$ & $5.3 \%$ & $13.4 \%$ & $2.2 \%$ & $6.8 \%$ & $3.0 \%$ & $100 \%$ & 980 \\
\hline \multicolumn{9}{|l|}{ Hungary } \\
\hline Actual & $46.6 \%$ & $2.8 \%$ & $22.5 \%$ & $0.2 \%$ & $17.6 \%$ & $10.3 \%$ & $100 \%$ & 630 \\
\hline Preferred & $71.2 \%$ & $7.1 \%$ & $5.9 \%$ & $2.8 \%$ & $8.0 \%$ & $5.1 \%$ & $100 \%$ & 630 \\
\hline \multicolumn{9}{|l|}{ Spain } \\
\hline Actual & $37.3 \%$ & $7.8 \%$ & $32.0 \%$ & $0.6 \%$ & $14.1 \%$ & $8.2 \%$ & $100 \%$ & 835 \\
\hline Preferred & $61.5 \%$ & $16.4 \%$ & $12.7 \%$ & $5.0 \%$ & $2.2 \%$ & $2.2 \%$ & $100 \%$ & 835 \\
\hline \multicolumn{9}{|l|}{ Slovenia } \\
\hline Actual & $54.6 \%$ & $3.0 \%$ & $16.7 \%$ & $0.0 \%$ & $15.6 \%$ & $10.2 \%$ & $100 \%$ & 540 \\
\hline Preferred & $85.0 \%$ & $4.3 \%$ & $3.0 \%$ & $3.3 \%$ & $1.3 \%$ & $3.2 \%$ & $100 \%$ & 540 \\
\hline \multicolumn{9}{|l|}{ Ireland } \\
\hline Actual & $22.8 \%$ & $15.0 \%$ & $29.2 \%$ & $2.4 \%$ & $23.2 \%$ & $7.5 \%$ & $100 \%$ & 950 \\
\hline Preferred & $39.2 \%$ & $32.5 \%$ & $9.0 \%$ & $9.3 \%$ & $7.0 \%$ & $3.1 \%$ & $100 \%$ & 950 \\
\hline
\end{tabular}

Notes: Own analysis of the European Social Survey, Round 5; results are weighted. Abbreviations: DBdual breadwinners, MMB-modified male breadwinners, MB-male breadwinners, DPT-dual part-timers, NB-no breadwinner model, FB-female breadwinners. 
To allow for a structured presentation of the rich descriptive evidence shown in Tables 1 and 2, we loosely group the 16 countries analysed into five patterns of results based on similarity in terms of shares of couples living certain breadwinner models and the prevalence of certain types of mismatch:

(a) Great Britain, the Netherlands, and Switzerland: If preferences were realised in these countries, we would observe a shift from male breadwinner models to modified male breadwinner models with some of the currently non-employed women taking up parttime jobs. The cross-tabulation of actual and preferred arrangements (Table 2) shows that around $45 \%$ of male breadwinner couples in the Netherlands and Switzerland would prefer a modified male breadwinner model ( $38 \%$ in Britain).

(b) Belgium, France, and Germany: If preferences were realised, increasing shares of both modified male breadwinner and dual breadwinner models would be observed, while shares of single breadwinners would decline. In Germany, only $20 \%$ of those in male breadwinner models prefer this arrangement, $45 \%$ prefer a modified male breadwinner model and $26 \%$ a dual breadwinner model. Belgium shows a very similar pattern. In France only $16 \%$ of those in male breadwinner models are content with this arrangement, whereas $50 \%$ would in fact prefer to be dual full-time earners and another $26 \%$ prefer a modified male breadwinner model. France shows some similarities also with pattern c.

(c) Denmark, Finland, Norway, and Sweden: The majority of couples are and prefer to be dual breadwinners. In Finland, Sweden, and Norway more than $90 \%$ of dual breadwinners hold a preference for this arrangement ( $83 \%$ in Denmark). Moreover, in Finland, Sweden, and Norway more than $40 \%$ of modified male breadwinners prefer a dual breadwinner model (26\% in Denmark). France shows some similarities with this pattern (i.e., very high share of satisfied dual breadwinners and $43 \%$ of modified male breadwinners preferring to switch to a dual breadwinner model).

(d) Estonia, Greece, Hungary, Slovenia, and Spain: In the Southern and Central/Eastern European countries dual-earner arrangements are much more often preferred than realised. The preference for the dual breadwinner model is strongly pronounced $(85 \%$ of couples in Slovenia, $71 \%$ in Hungary, $69 \%$ in Estonia and Greece, and $62 \%$ in Spain), but can often not be realised due to a lack of jobs. For this reason, we find many involuntary single-earner and no-breadwinner couples. The shares of male breadwinners who prefer a dual-earner model, for example, amount to $90 \%$ in Slovenia, $80 \%$ in Hungary, $74 \%$ in Estonia, $71 \%$ in Greece, and $66 \%$ in Spain (i.e., sum of dual breadwinner and modified male breadwinner models).

(e) Ireland: Similar to Southern and Central/Eastern Europe, Ireland has been strongly affected by the recession. This is reflected in high rates of no-breadwinner couples $(23 \%$, Table 1). However, in contrast to these countries, Ireland has a tradition of female part-time work, and a sizable share of Irish couples prefer the modified male breadwinner model (33\%). Yet, we observe an acute gap between preferences and behaviour: Whereas $72 \%$ of couples hold a preference for a dual-earner model, only $38 \%$ of couples can actually achieve such a model. 
Table 2: Actual and preferred couple employment arrangements, 2010-2012

\begin{tabular}{|c|c|c|c|c|c|c|c|c|}
\hline & \multicolumn{8}{|c|}{ Preferred arrangements } \\
\hline & DB & MMB & MB & DPT & NB & FB & Total & $\mathbf{N}$ \\
\hline \multicolumn{9}{|c|}{ Actual arrangements } \\
\hline \multicolumn{9}{|c|}{ Great Britain } \\
\hline$D B$ & $62.1 \%$ & $21.5 \%$ & $2.9 \%$ & $9.3 \%$ & $0.8 \%$ & $3.5 \%$ & $100 \%$ & 322 \\
\hline$M M B$ & $10.2 \%$ & $65.4 \%$ & $6.3 \%$ & $13.0 \%$ & $5.1 \%$ & $0.0 \%$ & $100 \%$ & 193 \\
\hline$M B$ & $22.3 \%$ & $38.3 \%$ & $27.4 \%$ & $5.6 \%$ & $6.4 \%$ & $0.0 \%$ & $100 \%$ & 162 \\
\hline$N B$ & $10.6 \%$ & $18.9 \%$ & $10.1 \%$ & $29.8 \%$ & $27.9 \%$ & $2.9 \%$ & $100 \%$ & 95 \\
\hline$F B$ & [50.5\%] & {$[9.0 \%]$} & {$[6.3 \%]$} & {$[9.0 \%]$} & [13.5\%] & [11.7\%] & $100 \%$ & 49 \\
\hline \multicolumn{9}{|c|}{ Netherlands } \\
\hline$D B$ & $67.7 \%$ & $20.9 \%$ & $1.2 \%$ & $4.6 \%$ & $3.1 \%$ & $2.5 \%$ & $100 \%$ & 224 \\
\hline$M M B$ & $6.2 \%$ & $76.1 \%$ & $2.9 \%$ & $5.4 \%$ & $9.1 \%$ & $0.3 \%$ & $100 \%$ & 294 \\
\hline$M B$ & $12.2 \%$ & $45.3 \%$ & $28.8 \%$ & $4.0 \%$ & $9.8 \%$ & $0.0 \%$ & $100 \%$ & 136 \\
\hline$N B$ & $6.8 \%$ & $19.8 \%$ & $14.1 \%$ & $18.6 \%$ & $40.7 \%$ & $0.0 \%$ & $100 \%$ & 77 \\
\hline$F B$ & [25.3\%] & [13.1\%] & {$[4.0 \%]$} & [11.1\%] & [5.1\%] & [41.4\%] & $100 \%$ & 44 \\
\hline \multicolumn{9}{|c|}{ Switzerland } \\
\hline$D B$ & $68.5 \%$ & $20.7 \%$ & $3.0 \%$ & $6.4 \%$ & $1.0 \%$ & $0.5 \%$ & $100 \%$ & 203 \\
\hline$M M B$ & $6.1 \%$ & $81.2 \%$ & $4.1 \%$ & $5.1 \%$ & $3.6 \%$ & $0.0 \%$ & $100 \%$ & 197 \\
\hline$M B$ & $16.8 \%$ & $45.8 \%$ & $29.0 \%$ & $3.9 \%$ & $3.2 \%$ & $1.3 \%$ & $100 \%$ & 155 \\
\hline$N B$ & [12.1\%] & [42.4\%] & [27.3\%] & [0.0\%] & [18.2\%] & [0.0\%] & $100 \%$ & 33 \\
\hline$F B$ & [53.6\%] & [7.1\%] & [3.6\%] & [14.3\%] & [3.6\%] & [17.9\%] & $100 \%$ & 28 \\
\hline \multicolumn{9}{|c|}{ Belgium } \\
\hline$D B$ & $79.0 \%$ & $13.4 \%$ & $1.2 \%$ & $4.0 \%$ & $0.9 \%$ & $1.5 \%$ & $100 \%$ & 329 \\
\hline$M M B$ & $14.6 \%$ & $78.5 \%$ & $0.8 \%$ & $5.4 \%$ & $0.0 \%$ & $0.8 \%$ & $100 \%$ & 130 \\
\hline$M B$ & $26.6 \%$ & $41.1 \%$ & $26.6 \%$ & $2.4 \%$ & $2.4 \%$ & $0.8 \%$ & $100 \%$ & 124 \\
\hline$N B$ & $31.4 \%$ & $28.8 \%$ & $11.0 \%$ & $14.4 \%$ & $13.6 \%$ & $0.9 \%$ & $100 \%$ & 118 \\
\hline$F B$ & $54.0 \%$ & $8.0 \%$ & $0.0 \%$ & $14.0 \%$ & $4.0 \%$ & $20.0 \%$ & $100 \%$ & 50 \\
\hline \multicolumn{9}{|c|}{ France } \\
\hline$D B$ & $85.2 \%$ & $7.3 \%$ & $1.1 \%$ & $1.2 \%$ & $2.4 \%$ & $2.1 \%$ & $100 \%$ & 340 \\
\hline$M M B$ & $43.0 \%$ & $50.7 \%$ & $2.5 \%$ & $1.3 \%$ & $2.6 \%$ & $0.0 \%$ & $100 \%$ & 70 \\
\hline$M B$ & $49.6 \%$ & $25.7 \%$ & $15.5 \%$ & $2.3 \%$ & $6.1 \%$ & $0.8 \%$ & $100 \%$ & 106 \\
\hline$N B$ & $48.4 \%$ & $15.4 \%$ & $6.2 \%$ & $10.3 \%$ & $16.6 \%$ & $3.1 \%$ & $100 \%$ & 88 \\
\hline$F B$ & $61.1 \%$ & $8.3 \%$ & $0.0 \%$ & $3.6 \%$ & $8.2 \%$ & $18.9 \%$ & $100 \%$ & 64 \\
\hline \multicolumn{9}{|c|}{ Germany } \\
\hline$D B$ & $75.4 \%$ & $15.7 \%$ & $0.8 \%$ & $4.8 \%$ & $2.4 \%$ & $1.0 \%$ & $100 \%$ & 480 \\
\hline$M M B$ & $17.6 \%$ & $68.2 \%$ & $4.2 \%$ & $7.0 \%$ & $3.1 \%$ & $0.0 \%$ & $100 \%$ & 302 \\
\hline$M B$ & $25.6 \%$ & $44.6 \%$ & $20.0 \%$ & $3.6 \%$ & $6.2 \%$ & $0.0 \%$ & $100 \%$ & 263 \\
\hline$N B$ & $29.5 \%$ & $19.5 \%$ & $6.8 \%$ & $11.5 \%$ & $28.7 \%$ & $4.0 \%$ & $100 \%$ & 150 \\
\hline$F B$ & $54.3 \%$ & $4.2 \%$ & $0.0 \%$ & $8.0 \%$ & $8.4 \%$ & $25.1 \%$ & $100 \%$ & 76 \\
\hline \multicolumn{9}{|c|}{ Denmark } \\
\hline$D B$ & $82.9 \%$ & $6.4 \%$ & $0.4 \%$ & $4.2 \%$ & $3.3 \%$ & $2.9 \%$ & $100 \%$ & 456 \\
\hline$M M B$ & $25.8 \%$ & $62.9 \%$ & $3.2 \%$ & $4.8 \%$ & $3.2 \%$ & $0.0 \%$ & $100 \%$ & 62 \\
\hline$M B$ & $58.4 \%$ & $19.1 \%$ & $14.6 \%$ & $3.4 \%$ & $4.5 \%$ & $0.0 \%$ & $100 \%$ & 89 \\
\hline$N B$ & $53.3 \%$ & $10.0 \%$ & $0.0 \%$ & $5.0 \%$ & $23.3 \%$ & $8.3 \%$ & $100 \%$ & 60 \\
\hline$F B$ & $63.0 \%$ & $1.9 \%$ & $0.0 \%$ & $3.7 \%$ & $5.6 \%$ & $25.9 \%$ & $100 \%$ & 54 \\
\hline \multicolumn{9}{|c|}{ Finland } \\
\hline$D B$ & $93.5 \%$ & $2.9 \%$ & $0.5 \%$ & $1.1 \%$ & $1.1 \%$ & $0.9 \%$ & $100 \%$ & 443 \\
\hline$M M B$ & [43.9\%] & [48.8\%] & {$[0.0 \%]$} & [4.9\%] & [2.4\%] & {$[0.0 \%]$} & $100 \%$ & 41 \\
\hline$M B$ & $63.6 \%$ & $12.6 \%$ & $16.1 \%$ & $5.6 \%$ & $2.1 \%$ & $0.0 \%$ & $100 \%$ & 143 \\
\hline$N B$ & $59.8 \%$ & $4.6 \%$ & $2.3 \%$ & $12.6 \%$ & $14.9 \%$ & $5.8 \%$ & $100 \%$ & 87 \\
\hline$F B$ & $64.0 \%$ & $2.3 \%$ & $0.0 \%$ & $7.9 \%$ & $3.4 \%$ & $22.5 \%$ & $100 \%$ & 89 \\
\hline
\end{tabular}




\begin{tabular}{|c|c|c|c|c|c|c|c|c|}
\hline & \multicolumn{8}{|c|}{ Preferred arrangements } \\
\hline & DB & MMB & MB & DPT & NB & FB & Total & $\mathbf{N}$ \\
\hline \multicolumn{9}{|c|}{ Sweden } \\
\hline$D B$ & $92.5 \%$ & $3.3 \%$ & $0.7 \%$ & $1.9 \%$ & $0.2 \%$ & $1.4 \%$ & $100 \%$ & 427 \\
\hline$M M B$ & $44.3 \%$ & $42.6 \%$ & $1.6 \%$ & $4.9 \%$ & $3.3 \%$ & $3.3 \%$ & $100 \%$ & 61 \\
\hline$M B$ & $76.1 \%$ & $11.3 \%$ & $5.6 \%$ & $2.8 \%$ & $4.2 \%$ & $0.0 \%$ & $100 \%$ & 71 \\
\hline$N B$ & [62.1\%] & [6.9\%] & {$[0.0 \%]$} & [17.2\%] & [13.8\%] & [0.0\%] & $100 \%$ & 29 \\
\hline$F B$ & [67.4\%] & [2.3\%] & {$[0.0 \%]$} & [4.7\%] & [4.7\%] & [20.9\%] & $100 \%$ & 43 \\
\hline \multicolumn{9}{|c|}{ Norway } \\
\hline$D B$ & $92.7 \%$ & $4.7 \%$ & $0.2 \%$ & $1.3 \%$ & $0.0 \%$ & $1.0 \%$ & $100 \%$ & 428 \\
\hline$M M B$ & $39.5 \%$ & $54.3 \%$ & $1.0 \%$ & $2.4 \%$ & $0.0 \%$ & $2.7 \%$ & $100 \%$ & 123 \\
\hline$M B$ & $66.9 \%$ & $23.3 \%$ & $7.9 \%$ & $1.0 \%$ & $1.0 \%$ & $0.0 \%$ & $100 \%$ & 97 \\
\hline$N B$ & $53.9 \%$ & $16.4 \%$ & $3.8 \%$ & $12.6 \%$ & $10.1 \%$ & $3.3 \%$ & $100 \%$ & 61 \\
\hline$F B$ & $64.3 \%$ & $4.0 \%$ & $0.0 \%$ & $2.2 \%$ & $1.9 \%$ & $27.7 \%$ & $100 \%$ & 53 \\
\hline \multicolumn{9}{|c|}{ Estonia } \\
\hline$D B$ & $75.5 \%$ & $4.8 \%$ & $3.0 \%$ & $1.8 \%$ & $12.5 \%$ & $2.4 \%$ & $100 \%$ & 335 \\
\hline$M M B$ & [58.3\%] & [13.9\%] & [2.8\%] & [11.1\%] & [13.9\%] & {$[0.0 \%]$} & $100 \%$ & 36 \\
\hline$M B$ & $61.0 \%$ & $13.2 \%$ & $13.7 \%$ & $2.8 \%$ & $6.6 \%$ & $2.8 \%$ & $100 \%$ & 182 \\
\hline$N B$ & $54.6 \%$ & $10.9 \%$ & $3.6 \%$ & $12.7 \%$ & $18.2 \%$ & $0.0 \%$ & $100 \%$ & 55 \\
\hline$F B$ & $75.8 \%$ & $3.2 \%$ & $4.8 \%$ & $1.6 \%$ & $11.3 \%$ & $3.2 \%$ & $100 \%$ & 62 \\
\hline \multicolumn{9}{|c|}{ Greece } \\
\hline$D B$ & $85.3 \%$ & $2.3 \%$ & $4.3 \%$ & $0.6 \%$ & $4.4 \%$ & $3.3 \%$ & $100 \%$ & 280 \\
\hline$M M B$ & [80.3\%] & [12.8\%] & [1.7\%] & [3.4\%] & [1.7\%] & [0.0\%] & $100 \%$ & 47 \\
\hline$M B$ & $62.8 \%$ & $8.2 \%$ & $18.3 \%$ & $1.7 \%$ & $8.1 \%$ & $0.8 \%$ & $100 \%$ & 377 \\
\hline$N B$ & $56.2 \%$ & $2.6 \%$ & $24.4 \%$ & $3.0 \%$ & $10.2 \%$ & $3.7 \%$ & $100 \%$ & 189 \\
\hline$F B$ & $77.3 \%$ & $3.5 \%$ & $2.0 \%$ & $0.0 \%$ & $3.5 \%$ & $13.6 \%$ & $100 \%$ & 77 \\
\hline \multicolumn{9}{|c|}{ Hungary } \\
\hline$D B$ & $85.4 \%$ & $6.8 \%$ & $2.0 \%$ & $1.7 \%$ & $2.8 \%$ & $1.3 \%$ & $100 \%$ & 294 \\
\hline$M M B$ & - & - & - & - & - & - & $100 \%$ & 18 \\
\hline$M B$ & $70.0 \%$ & $10.4 \%$ & $14.8 \%$ & $0.7 \%$ & $2.1 \%$ & $2.1 \%$ & $100 \%$ & 142 \\
\hline$N B$ & $42.0 \%$ & $3.6 \%$ & $7.2 \%$ & $7.3 \%$ & $32.7 \%$ & $7.2 \%$ & $100 \%$ & 110 \\
\hline$F B$ & $58.3 \%$ & $3.1 \%$ & $3.1 \%$ & $6.1 \%$ & $3.0 \%$ & $26.3 \%$ & $100 \%$ & 65 \\
\hline \multicolumn{9}{|l|}{ Spain } \\
\hline$D B$ & $84.6 \%$ & $5.8 \%$ & $2.6 \%$ & $5.0 \%$ & $0.3 \%$ & $1.7 \%$ & $100 \%$ & 315 \\
\hline$M M B$ & $42.5 \%$ & $35.6 \%$ & $6.0 \%$ & $14.6 \%$ & $0.0 \%$ & $1.4 \%$ & $100 \%$ & 63 \\
\hline$M B$ & $42.3 \%$ & $23.8 \%$ & $28.2 \%$ & $4.5 \%$ & $0.4 \%$ & $0.8 \%$ & $100 \%$ & 265 \\
\hline$N B$ & $50.2 \%$ & $22.1 \%$ & $13.2 \%$ & $0.8 \%$ & $12.7 \%$ & $0.9 \%$ & $100 \%$ & 117 \\
\hline$F B$ & $70.7 \%$ & $5.7 \%$ & $4.2 \%$ & $5.4 \%$ & $1.5 \%$ & $12.5 \%$ & $100 \%$ & 70 \\
\hline \multicolumn{9}{|c|}{ Slovenia } \\
\hline$D B$ & $90.2 \%$ & $4.1 \%$ & $1.4 \%$ & $2.0 \%$ & $1.0 \%$ & $1.4 \%$ & $100 \%$ & 295 \\
\hline$M M B$ & - & - & - & - & - & - & $100 \%$ & 16 \\
\hline$M B$ & $83.3 \%$ & $6.7 \%$ & $3.3 \%$ & $4.4 \%$ & $1.1 \%$ & $1.1 \%$ & $100 \%$ & 90 \\
\hline$N B$ & $77.4 \%$ & $1.2 \%$ & $4.8 \%$ & $7.1 \%$ & $2.4 \%$ & $7.1 \%$ & $100 \%$ & 84 \\
\hline$F B$ & $78.2 \%$ & $1.8 \%$ & $7.3 \%$ & $1.8 \%$ & $1.8 \%$ & $9.1 \%$ & $100 \%$ & 55 \\
\hline \multicolumn{9}{|c|}{ Ireland } \\
\hline$D B$ & $66.9 \%$ & $19.7 \%$ & $1.7 \%$ & $5.7 \%$ & $1.1 \%$ & $4.9 \%$ & $100 \%$ & 227 \\
\hline$M M B$ & $18.7 \%$ & $66.3 \%$ & $2.9 \%$ & $8.1 \%$ & $4.0 \%$ & $0.0 \%$ & $100 \%$ & 131 \\
\hline$M B$ & $27.7 \%$ & $36.0 \%$ & $21.2 \%$ & $7.8 \%$ & $6.6 \%$ & $0.6 \%$ & $100 \%$ & 268 \\
\hline$N B$ & $35.6 \%$ & $23.0 \%$ & $8.2 \%$ & $14.8 \%$ & $15.8 \%$ & $2.6 \%$ & $100 \%$ & 225 \\
\hline$F B$ & $58.4 \%$ & $11.6 \%$ & $0.0 \%$ & $6.9 \%$ & $7.5 \%$ & $15.6 \%$ & $100 \%$ & 78 \\
\hline
\end{tabular}

Notes: Own analysis of the European Social Survey, Round 5; results are weighted. Abbreviations: DBdual breadwinners, MMB-modified male breadwinners, MB-male breadwinners, DPT-dual part-timers, NB-no breadwinner model, FB-female breadwinners. Dual part-timers (DPT) excluded as too low sample sizes in all countries. Values in parentheses to be interpreted with caution due to low sample sizes (below 50). 


\section{The prevalence and determinants of hours mismatches}

Table 3: Multinomial logistic regression analysis: Couple underemployment and overemployment

\begin{tabular}{|c|c|c|c|c|c|c|}
\hline & \multicolumn{2}{|c|}{ Match } & \multicolumn{2}{|c|}{ Under } & \multicolumn{2}{|c|}{ Over } \\
\hline & ME & SE & ME & SE & ME & SE \\
\hline Female respondent & $-0.035^{\star * *}$ & $(0.009)$ & $0.040^{* * *}$ & $(0.008)$ & -0.004 & $(0.006)$ \\
\hline Age of the woman & $0.002^{*}$ & $(0.001)$ & $-0.002^{*}$ & $(0.001)$ & 0.000 & $(0.001)$ \\
\hline Age of the man & -0.001 & $(0.001)$ & 0.000 & $(0.001)$ & 0.001 & $(0.001)$ \\
\hline \multicolumn{7}{|l|}{ Education of the woman (low) } \\
\hline Medium & $0.081^{* * *}$ & $(0.014)$ & $-0.104^{\star * *}$ & $(0.013)$ & $0.023^{\star *}$ & $(0.008)$ \\
\hline High & $0.161^{* * *}$ & $(0.014)$ & $-0.208^{* * *}$ & $(0.014)$ & $0.047^{* * *}$ & $(0.008)$ \\
\hline \multicolumn{7}{|l|}{ Education of the man (low) } \\
\hline Medium & $0.063^{* * *}$ & $(0.014)$ & $-0.069^{* * *}$ & $(0.013)$ & 0.005 & $(0.009)$ \\
\hline High & $0.092^{* * *}$ & $(0.014)$ & $-0.106^{* * *}$ & $(0.014)$ & 0.014 & $(0.009)$ \\
\hline \multicolumn{7}{|l|}{ Family life-cycle (childless) } \\
\hline Youngest child in $\mathrm{HH}$ age $<6$ & $-0.056^{\star * *}$ & $(0.014)$ & $0.045^{\star * *}$ & $(0.013)$ & 0.011 & $(0.009)$ \\
\hline Youngest child in $\mathrm{HH} 6<12$ & 0.029 & $(0.016)$ & $-0.045^{\star *}$ & $(0.015)$ & 0.016 & $(0.010)$ \\
\hline Youngest child in $\mathrm{HH} 12<18$ & $0.037^{*}$ & $(0.018)$ & $-0.084^{* * *}$ & $(0.016)$ & $0.047^{\star * *}$ & $(0.012)$ \\
\hline Youngest child in $\mathrm{HH}$ aged $18+$ & -0.013 & $(0.019)$ & -0.021 & $(0.017)$ & $0.034^{* *}$ & $(0.012)$ \\
\hline No child in $\mathrm{HH}$ anymore & $-0.047^{*}$ & $(0.019)$ & $0.036^{*}$ & $(0.018)$ & 0.012 & $(0.011)$ \\
\hline \multicolumn{7}{|l|}{ Residence urban/rural (rural) } \\
\hline Small town & 0.002 & $(0.012)$ & 0.004 & $(0.011)$ & -0.006 & $(0.008)$ \\
\hline Big city & $0.028^{*}$ & $(0.011)$ & $-0.029^{* *}$ & $(0.010)$ & 0.001 & $(0.007)$ \\
\hline \multicolumn{7}{|l|}{ Country (Germany) } \\
\hline Great Britain & -0.009 & $(0.023)$ & $-0.098^{* \star *}$ & $(0.020)$ & $0.107^{\star \star *}$ & $(0.019)$ \\
\hline Netherlands & $0.106^{* * *}$ & $(0.023)$ & $-0.158^{* * *}$ & $(0.019)$ & $0.052^{* *}$ & $(0.018)$ \\
\hline Switzerland & $0.063^{\star *}$ & $(0.024)$ & $-0.085^{\star * *}$ & $(0.022)$ & 0.022 & $(0.018)$ \\
\hline Belgium & 0.034 & $(0.023)$ & -0.006 & $(0.022)$ & -0.029 & $(0.015)$ \\
\hline France & 0.039 & $(0.024)$ & -0.009 & $(0.022)$ & -0.030 & $(0.015)$ \\
\hline Denmark & $0.104^{* \star *}$ & $(0.023)$ & $-0.093^{* * *}$ & $(0.021)$ & -0.011 & $(0.016)$ \\
\hline Finland & $0.076^{\star \star *}$ & $(0.022)$ & 0.013 & $(0.021)$ & $-0.089^{* * *}$ & $(0.012)$ \\
\hline Sweden & $0.158^{\star * \star}$ & $(0.023)$ & $-0.090^{* * *}$ & $(0.022)$ & $-0.068^{* * *}$ & $(0.014)$ \\
\hline Norway & $0.094^{* * *}$ & $(0.022)$ & -0.005 & $(0.022)$ & $-0.089^{\star \star *}$ & $(0.012)$ \\
\hline Estonia & $-0.089^{* * *}$ & $(0.024)$ & $0.066^{\star *}$ & $(0.023)$ & 0.023 & $(0.017)$ \\
\hline Greece & $-0.122^{\star * *}$ & $(0.022)$ & $0.167^{\star \star \star}$ & $(0.021)$ & $-0.045^{\star *}$ & $(0.014)$ \\
\hline Hungary & 0.026 & $(0.024)$ & 0.027 & $(0.023)$ & $-0.053^{\star * *}$ & $(0.015)$ \\
\hline Spain & 0.004 & $(0.023)$ & 0.041 & $(0.022)$ & $-0.045^{\star \star}$ & $(0.015)$ \\
\hline Slovenia & 0.002 & $(0.026)$ & $0.072^{* *}$ & $(0.025)$ & $-0.074^{* * *}$ & $(0.014)$ \\
\hline Ireland & $-0.131^{* \star *}$ & $(0.022)$ & $0.135^{\star \star \star}$ & $(0.021)$ & -0.004 & $(0.015)$ \\
\hline
\end{tabular}

Sample: 12,103 cohabiting women and men in 16 countries. Shown are marginal effects (ME) derived from a multinomial logistic regression analysis. Standard errors (SE) in parentheses.

$* * * \mathrm{p}<0.001,{ }^{*} * \mathrm{p}<0.01, * \mathrm{p}<0.05$. 
In the pooled sample (all countries), the estimated share of couples whose employment pattern matched their preferences amounts to about $52 \%$, while about $34 \%$ of couples report to be underemployed and $11 \%$ reported to be overemployed (see Table A3 in the appendix for an overview of the distribution of mismatches in each country). In the multivariate regression context that controls for age, education, and the family life-cycle (Table 3 ), we find statistically higher rates of couple underemployment in Ireland, Greece, Estonia, and Slovenia compared to Germany that serves as the reference. Spain shows comparatively high rates of underemployment in the descriptive analyses (Table A3) but once we control for the educational composition of the national samples, Spain shows average levels of underemployment. Conversely, Great Britain and the Netherlands stand out as the countries with the highest prevalence of overemployment. This mainly owes to the comparatively large shares of dual-breadwinner couples who would prefer to live a modified male breadwinner model or a dual part-time model (cf. Table 2). Although the tradition of female part-time work in these two countries is strong, there still appears to be an unmet demand for even more part-time jobs.

The results shown in Table 3 confirm that higher levels of education are associated with a lower likelihood of couple underemployment and a higher chance of being able to put preferences into practice. The woman's and the man's education work similarly in this regard - with somewhat stronger effects of the woman's education. Moreover, the woman's education shows a positive correlation with the risk of overemployment.

Figure 1: Marginal effects of the family life-cycle on under- and overemployment of couples, by sex

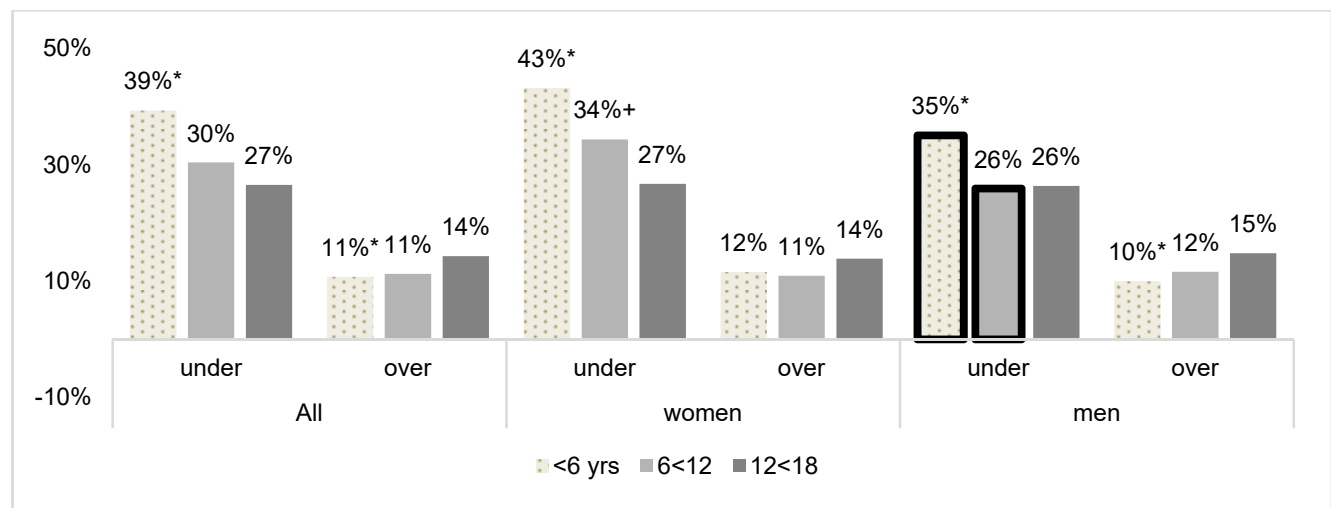

Notes: Own analysis of the European Social Survey, Round 5; results (marginal effects of children) are based on a sex-specific multinomial logistic regression analysis (same model as shown in Table 3).

$*$ denotes a significant differences $(\mathrm{p}<0.05)$ between parents of teenagers aged $12<18$ (reference group) and those whose youngest child is $<6$ yrs. + denotes that for women the difference in underemployment between all three life-cycle stages is significant at $\mathrm{p}<0.05$. The solid lines around two bars denote that the gender difference in the level of underemployment is significant only in the presence of children $<6$ years and $6<12$ years; no significant differences between women and men in terms of the occurrence of overemployment.

The estimated effects of the family life-cycle indicate that the risk of underemployment is significantly higher for parents with children below age 6 than for childless couples or 
parents of older children (Table 3, Figure 1). Couples whose youngest child is aged 12 and above, by contrast, face a significantly increased risk of overemployment. ${ }^{6}$

In terms of gender differences, the mismatch analysis (Table 3) suggests that women are somewhat more likely to report underemployment than men, in other words in some male breadwinner couples the woman prefers to increase her hours more than her partner prefers her to. However, we note that our substantive results regarding the impact of the family life-cycle on underemployment are robust to this gender difference in the reporting of mismatch. As illustrated in Figure 1, the risk of underemployment is significantly higher among parents of children below age 6 compared to parents of older children, irrespective of whether we survey fathers or mothers. However, the strength of child effects on the risk of underemployment is estimated to be somewhat stronger when asking mothers compared to asking fathers. Conversely, the impact of teenagers aged $12<18$ on the risk of overemployment is found to be significant only for fathers.

The impact of children on parents' risk of experiencing underemployment varies a lot across Europe (Figure 2). The general pattern found in the pooled sample which suggests that parents of children under age 6 are most at risk of underemployment is found in most countries (exceptions are Britain, Greece, Ireland, and Sweden). However, this effect of small children is most pronounced (and statistically significant only) in Estonia, Finland, Germany, Hungary, and Slovenia. In the CEE countries the strong impact of small children on underemployment can be explained with reference to the dominant family policy model that is characterised by a lack of public childcare combined with policies that financially reward full-time care-givers. Another explanation may be the lack of part-time opportunities that leaves parents with a choice between long full-time hours and nonemployment. The large effect of small children in Finland may be surprising given that Finland tends to be grouped with the Scandinavian countries in terms of welfare state and gender regimes. Yet, as observed in prior studies (e.g., Saraceno/Keck 2010), Finland shares some similarities with CEE regarding family policy and a lack of part-time opportunities. In Scandinavia (Denmark, Sweden, and Norway), by contrast, underemployment is generally low and small children do not elevate parents' risk of underemployment (which may be expected given a policy setup that facilitates parental employment through public childcare). France and Belgium show some similarities with Scandinavia in terms of care policy (Saraceno/Keck 2010), which can explain the small and non-significant effects of children also in these two countries. Also for Britain and the Netherlands, we find a very small difference between parents of smaller or older children in terms of the risk of mismatch (despite the lack of an adequate childcare infrastructure in these countries), which may be due to the wide availability of part-time jobs. In Germany, we find parents of small children to face a significantly elevated risk of underemployment, despite a relatively wide availability of part-time jobs, yet the childcare infrastructure is weak in supporting parental (full-time) employment. Finally, in Southern Europe (Greece and Spain) and Ireland, we find little variation of the generally very high risk of underemployment

6 A test of the interaction effect between education and the family life-cycle suggests that these results do not vary across educational groups (available upon request). A supplementary model with an alternative specification including the number of children aged below 18 as a predictor instead of the family life-cycle (available upon request) suggests that the risk of underemployment decreases when the couple has more than one child, while the risk of overemployment increases. 
across the family life-cycle. The cross-country comparative analysis of child effects is restricted to the issue of underemployment, because cell sizes within different life-cycle stages are too small for a similar analysis of overemployment.

Figure 2: Marginal effects of the family life-cycle on underemployment of couples, by country

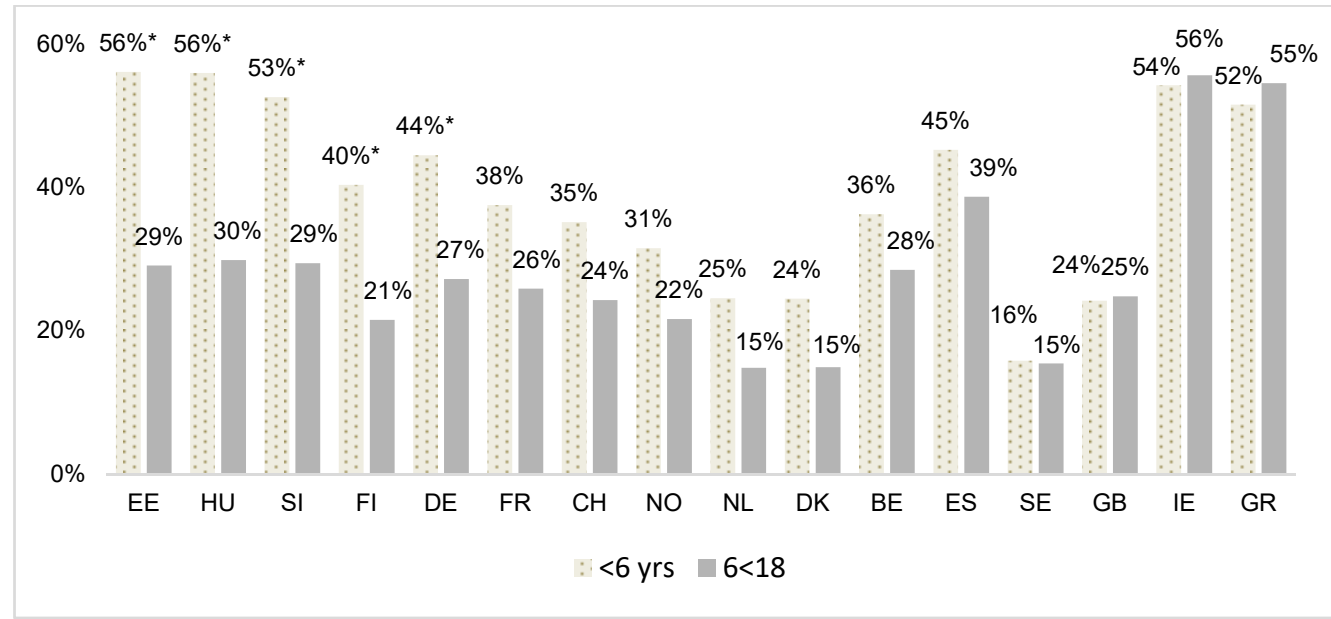

Notes: Own analysis of the European Social Survey, Round 5; results (marginal effects of children) are based on a country-specific multinomial logistic regression analysis (same model as shown in Table 3).

* denotes that the difference between parents of children aged $6<18$ years (reference group) and $<6$ years is significant at $\mathrm{p}<0.05$. The order of countries in this figure is based on the difference in \%-points between the two groups of parents.

\section{Concluding discussion}

As shown in this study, in the observation period 2010-2012, i.e., in the aftermath of the recession, we find a great deal of mismatch between the number of hours that European couples would prefer to work and the jobs that they are able to obtain. The phenomenon of couple underemployment was found to be most prevalent in Southern Europe, Central and Eastern Europe, and Ireland, where heavily restricted employment opportunities resulted in large shares of underemployed couples, in particular in the wide-spread underemployment of women who would prefer to contribute to the household income but are unable to obtain (full-time) jobs.

In prior research on this topic, the phenomenon of underemployed couples was mainly explained with reference to insufficient childcare facilities that do not allow parents to work as many hours as they would prefer (e.g., Tsang et al. 2014). At the same time, some prior studies suggest that parents tend to report preferences for work hours reductions (i.e., the risk of overemployment). The present study shows that these mixed findings are due to the fact that the risk of hours mismatch varies along the family life-cycle: whereas mothers' and fathers' risk of underemployment is elevated as long as they have a 
child below school age (plausibly due to a lack of childcare options), once their children become older (from age 12 onwards) fathers face an increased risk of overemployment. The cross-country comparative analysis furthermore suggested that the impact of small children on the experience of parental underemployment varies across Europe. Due to the relatively small number of countries analysed and the limited samples sizes within countries, the results of the comparative analysis allow only for tentative conclusions. The pattern of results indicates a particularly strong impact of children below school age on underemployment in countries that offer limited part-time opportunities and an inadequate childcare infrastructure. The comparatively strongest association between the presence of children below age 6 and parental underemployment was found in the post-socialist countries studied (Estonia, Hungary, Slovenia), Finland, and Germany.

Another key finding of the study was that a high level of education can protect couples from underemployment. Conversely, a high level of education (especially women's education) increases the risk of overemployment. This corroborates theories of a 'new lumpiness of labour', suggesting that jobs in skilled occupations tend to involve specialised knowledge, high levels of responsibility and autonomous decision-making and may therefore demand longer hours than may be desired by the incumbent.

The study has important policy implications insofar as it shows work hours mismatches in Europe to be very widespread with negative consequences for individuals' and families' economic welfare (i.e., underemployment) and well-being (under-and overemployment have been shown to negatively affect health). The study also gives new insights into the demographic risk factors for the occurrence of hours mismatches in Europe. The population groups most vulnerable to underemployment are those living in countries where the labour market offers limited employment opportunities (unemployment, lack of part-time jobs) and here in particular the low educated and parents of small children. Low wages that demand both partners to work full-time in order to make ends meet are a further factor likely to increase the risk of underemployment, especially in the post-socialist countries. Overemployment is mostly an issue for the better educated. Both types of mismatch have negative implications for individuals and their families and they indicate inefficiency in the societal allocation of time and money. Our findings thus suggest that reconciliation policies (at societal or organisational level) such as a good childcare infrastructure for small children and the development of high-quality part-time jobs would contribute to a reduction of harmful hours mismatches in Europe.

A limitation of the study pertains to the fact that the data used provides representative information only for a limited set of countries that do not allow for robust multi-level analyses. Once data for a larger set of countries and time points become available, future research will be able to investigate moderating effects of national labour market structures and institutional setups. The focus of this study is on couples in Europe. The analysis of population groups without partners such as single parents is a further avenue for future research.

\section{Acknowledgements}

This work was supported by funds of the Oesterreichische Nationalbank [Anniversary Fund, project number: 15010] for the project "Changes in Household Employment Patterns and Social Impacts of the Economic Crisis?" 


\section{References}

Altonji, J. G. \& Paxson, C. H. (1988). Labor supply preferences, hours constraints, and hours-wage tradeoffs. Journal of Labor Economics, 6, 2, pp. 254-276. doi: 10.1086/298183.

Bassanini, A., \& Caroli, E. (2015). Is work bad for health? The role of constraint versus choice. Annals of Economics and Statistics, 119, 120, pp. 13-37. doi: 10.15609/annaeconstat2009.119-120.13.

Becker, G.S. (1991). A treatise on the family. Cambridge, MA: Harvard University Press.

Bell, D., Otterbach, S. \& Sousa-Poza, A. (2012). Work hours constraints and health. Annals of Economics and Statistics, 105, 106, pp. 35-54. doi: 10.2307/23646455.

Bielenski ,H., Wagner, A. \& Bosch, G. (2002). Working time preferences in sixteen European countries. Dublin: Eurofound.

Blossfeld, H.P. \& Timm, A. (Eds.) (2003). Who marries whom? Educational systems as marriage markets in modern societies: A comparison of thirteen countries. Dordrecht: Kluwer. doi: 10.1007/978-94-007-1065-8.

Böheim, R. \& Taylor, M. P. (2004). Actual and preferred working hours. British Journal of Industrial Relations, 42, 1, pp. 149-166. doi: 10.1111/j.1467-8543.2004.00308.x.

Clarkberg, M. \& Moen, P. (2001). Understanding the time-squeeze married couples' preferred and actual work-hour strategies. American Behavioral Scientist, 44, 7, pp. 1115-1136. doi: 10.1177/0002764201044007005.

Del Boca, D. (2002). The effect of child care and part time opportunities on participation and fertility decisions in Italy. Journal of Population Economics, 15, 3, pp. 549-573. doi: $10.1007 / \mathrm{s} 001480100089$.

De Moortel, D., Thévenon, O., De Witte, H. \& Vanroelen, C. (2017). Working hours mismatch, macroeconomic changes and mental well-being in Europe. Journal of Health and Social Behavior, 58, 2, pp. 217-231. doi: 10.1177/0022146517706532.

Dooley, D. (2003). Unemployment, underemployment, and mental health: conceptualizing employment status as a continuum. American Journal of Community Psychology, 32, 1/2, pp. 9-20. doi: 10.1023/A:1025634504740.

Echtelt, P. E., van Glebbeek, A. C. \& Lindenberg, S. M. (2006). The new lumpiness of work explaining the mismatch between actual and preferred working hours. Work, Employment \& Society, 20, 3, pp. 493-512. doi: 10.1177/0950017006066998.

Erlinghagen, M. (2008). Self-perceived job insecurity and social context: A multi-level analysis of 17 European Countries. European Sociological Review, 24, 2, pp. 183-197. doi: $10.1093 /$ esr/jcm042.

Fagan, C. and Warren, T. (2001). Gender, employment and working time preferences in Europe. Dublin: European Foundation for the Improvement of Living and Working Conditions.

Gerson, K. (1985). Hard choices: How women decide about work, career, and motherhood. Berkeley: University of California Press. doi: 10.1525/j.cttlppth4.

Gesthuizen, M., Solga, H. \& Künster, R. (2011). Context matters: Economic marginalization of loweducated workers in cross-national perspective. European Sociological Review, 27, 2, pp. 264-280. doi: $10.1093 /$ esr/jcq006.

Gornick, J. C. \& Meyers, M. K. (2003). Welfare regimes in relation to paid work and care. Advances in Life Course Research, 8, pp. 45-67. doi: 10.1016/S1040-2608(03)08003-1.

Haas B., Steiber N., Hartel M. and Wallace C. (2006) Household employment patterns in an enlarged European Union. Work, Employment \& Society, 20, 4, pp. 751-771. doi: $10.1177 / 0950017006069813$.

Hamermesh, D. S. \& Pfann, G. A. (1996). Adjustment costs in factor demand. Journal of Economic Literature, 34,3 , pp. 1264-1292.

Horemans, J., Marx, I. \& Nolan, B. (2016). Hanging in, but only just: part-time employment and in-work poverty throughout the crisis. IZA Journal of European Labor Studies, 5, 1, pp. 1-19. doi: 10.1186/s40174-016-0053-6. 
Jacobs, J. A. \& Gerson, K. (2001). Overworked individuals or overworked families? Explaining trends in work, leisure, and family time. Work and Occupations, 28, 19, pp. 40-63. doi: $10.1177 / 0730888401028001004$.

Jacobs, J. A. \& Gerson, K. (2004). The time divide: Work, family, and gender inequality, Cambridge: Harvard University Press. doi: 10.1111/j.1741-3737.2005.00173.x.

Jacobs, J. A. \& Green, K. (1998). Who are the overworked Americans? Review of Social Economy, 56, 4, pp. 442-459. doi: 10.1080/00346769800000044.

Konietzka, D. \& Kreyenfeld, M. (2010). The growing educational divide in mothers' employment: an investigation based on the German micro-censuses 1976-2004. Work, Employment \& Society, 24, 2, pp. 260278. doi: 10.1177/0950017010362140.

Lewis, J., Campbell, M. \& Huerta, C. (2008). Patterns of paid and unpaid work in Western Europe: Gender, commodification, preferences and the implications for policy. Journal of European Social Policy, 18, 1, pp. 21-37. doi: 10.1177/0958928707084450.

Merz, J. (2002). Time and economic well-being: A panel analysis of desired versus actual working hours. Review of Income and Wealth, 48, 3, pp. 317-346. doi: 10.1111/1475-4991.00057.

Moen, P. \& Dempster-McClain, D. I. (1987). Employed parents: Role strain, work time, and preferences for working less. Journal of Marriage and the Family, 49, 3, pp. 579-590. doi: 10.2307/352203.

OECD (2001). OECD employment outlook 2001. Paris: OECD Publishing. doi: 10.1787/19991266.

OECD (2010). How good is part-time work? (Chapter 4). In: Employment outlook 2010: moving beyond the jobs crisis. Paris: OECD Publishing. doi: 10.1787/19991266.

Otterbach, S. (2010). Mismatches between actual and preferred work time: empirical evidence of hours constraints in 21 countries. Journal of Consumer Policy, 33, 2, pp. 143-161. doi: 10.1007/s10603-009-9116-7.

Pettit, B. \& Hook, J. (2005). The structure of women's employment in comparative perspective. Social Forces, 84, 2, pp. 779-801. doi: 10.1353/sof.2006.0029.

Reynolds, J. (2003). You can't always get the hours you want: Mismatches between actual and preferred work hours in the U.S. Social Forces, 81, 4, pp. 1171-1199. doi: 10.1353/sof.2003.0069.

Reynolds, J. (2014). Prevailing preferences: actual work hours and work-hour preferences of partners. Industrial \& Labor Relations Review, 67, 3, pp. 1017-1041. doi: 10.1177/0019793914537459.

Reynolds, J. \& Aletraris, L. (2006). Pursuing preferences: the creation and resolution of work hour mismatches. American Sociological Review, 71, 4, pp. 618-638. doi: 10.1177/000312240607100405.

Reynolds, J. \& Johnson, D. R. (2012). Don't blame the babies: work hour mismatches and the role of children. Social Forces, 91, 1, pp. 131-155. doi: 10.1093/sf/sos070.

Rubery, J. \& Rafferty, A. (2013). Women and recession revisited. Work, Employment \& Society, 27, 3, pp. 414-432. doi: 10.1177/0950017012460314.

Saraceno, C. \& Keck, W. (2010). Can we identify intergenerational policy regimes in Europe? European Societies, 12, 5, pp. 675-696. doi: 10.1080/14616696.2010.483006.

Schwartz, C. \& Mare, R. (2005). Trends in educational assortative marriage from 1940 to 2003. Demography, 42, 4, pp. 621-646. doi: 10.1353/dem.2005.0036.

Sousa-Poza, A. \& Henneberger, F. (2002). An empirical analysis of working-hours constraints in twentyone countries. Review of Social Economy, 60, 2, pp. 209-242. doi: 10.1080/00346760210146235.

Steiber, N. and Haas, B. (2012) Advances in explaining women's employment patterns. Socio-Economic Review, 10, 2, pp. 343-367. doi: 10.1080/00346760210146235.

Steiber, N., Berghammer, C. \& Haas, B. (2016). Contextualizing the education effect on women's employment: A cross-national comparative analysis, Journal of Marriage and Family, 78, 1, pp. 246261. doi: 10.1111 jomf.12256.

Stier, H. \& Lewin-Epstein, N. (2003). Time to work: a comparative analysis of preferences for working hours. Work and Occupations, 30, 3, pp. 302-326. doi: 10.1177/0730888403253897.

Tsang, F., Rendall, M., Rohr, C. \& Hoorens, S. (2014). Emerging trends in earnings structures of couples in Europe: Short statistical report No. 5. Santa Monica: RAND Corporation.

doi: $10.2838 / 54302$. 
Väisänen, M. \& Nätti, J. (2002). Working time preferences in dual-earning households. European Societies, 4, 3, pp. 307-329. doi: 10.2838/54302.

Warren, T. (2015). Work-time underemployment and financial hardship: class inequalities and reces-sion in the UK. Work, Employment and Society, 29, 2, pp. 191-212. doi: 10.1177/0950017014559264.

Wilkins, R. (2006). Personal and job characteristics associated with underemployment. Australian Journal of Labour Economics, 9, 4, pp. 371-393.

Wilkins, R. \& Wooden, M. (2011). Economic approaches to studying underemployment. In: Maynard, D. \& Feldman, D. C. (Eds.), Underemployment: Psychological, economic, and social challenges. Springer Science+Business Media, pp. 13-34. doi: 10.1007/978-1-4419-9413-.4.

Wooden, M., Warren, D. \& Drago, R. (2009). Working time mismatch and subjective well-being. British Journal of Industrial Relations, 47, 1, pp. 147-179. doi: 10.1111/j.1467-8543.2008.00705.x.

Wunder, C. \& Heineck, G. (2013). Working time preferences, hours mismatch and well-being of couples: are there spillovers? Labour Economics 24, pp. 244-252. doi: 10.1016/j.labeco.2013.09.002.

Submitted on/Eingereicht am: 02.05.2018

Accepted on/Angenommen am: 23.10.2018

Addresses of the authors/Anschriften der Autor(inn)en:

Dr. Nadia Steiber (Corresponding author/Korrespondierende Autorin)

Institute for Advanced Studies

Josefstädter Strasse 39

1080 Vienna

Austria/Österreich

Wittgenstein Centre for Demography and Global Human Capital (IIASA, VID/ÖAW, WU)

International Institute for Applied Systems Analysis

Schlossplatz 1

2361 Laxenburg

Austria/Österreich

Email/E-Mail: steiber@ihs.ac.at

Privatdozentin Dr. Barbara Haas

Department of Socioeconomics

Vienna University of Economics and Business

Welthandelsplatz 1

1090 Vienna

Austria/Österreich

Email/E-Mail: barbara.haas@wu.ac.at 


\section{Appendix}

Table A1: Mean numbers of actual and preferred hours in couples, by couple employment arrangement

\begin{tabular}{lllrrrrr}
\hline Reported hours dimension & Reported by & \multicolumn{3}{c}{ Current breadwinner model } \\
& & DB & MMB & MB & FB & DPT & LI \\
\hline \multirow{2}{*}{ own hrs } & Man & 45.1 & 44.9 & 45.5 & 3.7 & 13.4 & 1.6 \\
& Woman & 40.3 & 18.6 & 0.0 & 39.3 & 17.8 & 2.6 \\
partner hrs & Man & 39.2 & 18.4 & 0.0 & 39.6 & 15.7 & 2.3 \\
& Woman & 43.4 & 43.1 & 43.4 & 3.7 & 17.5 & 1.7 \\
own preferred hrs & Man & 38.2 & 35.8 & 37.3 & 32.1 & 32.6 & 31.6 \\
& Woman & 33.4 & 22.5 & 24.5 & 34.3 & 23.1 & 24.3 \\
preferred hrs for partner & Man & 33.4 & 20.5 & 18.8 & 32.5 & 23.8 & 20.5 \\
& Woman & 37.0 & 37.3 & 37.6 & 28.4 & 30.2 & 26.7 \\
mismatch own hrs & Man & -6.9 & -9.1 & -8.2 & 28.4 & 19.2 & 30.0 \\
& Woman & -6.9 & 3.9 & 24.5 & -5.0 & 5.3 & 21.7 \\
mismatch partner hrs & Man & -5.8 & 2.1 & 18.8 & -7.1 & 8.1 & 18.2 \\
& Woman & -6.4 & -5.8 & -5.8 & 24.7 & 12.7 & 25.0 \\
\hline
\end{tabular}

Note: Shown are (weighted) mean numbers of actual and preferred hours and hours mismatch (measured in mean hours) as reported by men and women in different breadwinner models (Table 1 for abbreviations).

Table A2: Coding of couple underemployment and overemployment

\begin{tabular}{|c|c|c|c|c|c|c|}
\hline \multirow[b]{2}{*}{ Actual Arrangements } & \multicolumn{6}{|c|}{ Preferred Arrangements } \\
\hline & DB & MMB & MB & DPT & NB & FB \\
\hline$D B$ & match & over & over & over & over & over \\
\hline MMB & under & match & over & over & over & a \\
\hline MB & under & under & match & a & over & a \\
\hline$D P T$ & under & under & a & match & over & a \\
\hline NB & under & under & under & under & match & under \\
\hline$F B$ & under & $\mathrm{a}$ & $\mathrm{a}$ & a & over & match \\
\hline
\end{tabular}

Note: Combinations marked with an 'a' are excluded from the sample (about $2 \%$ of the sample, see Table A3), because they cannot clearly be defined as under- or overemployed (see Table 1 for abbreviations). 
Table A3: Distribution of couple underemployment and overemployment, by country

\begin{tabular}{|c|c|c|c|c|c|c|}
\hline & Match & Under & Over & a & Total & $\mathbf{N}$ \\
\hline Great Britain & $49 \%$ & $27 \%$ & $22 \%$ & $3 \%$ & $100 \%$ & 838 \\
\hline Netherlands & $60 \%$ & $20 \%$ & $18 \%$ & $2 \%$ & $100 \%$ & 787 \\
\hline Switzerland & $58 \%$ & $25 \%$ & $15 \%$ & $2 \%$ & $100 \%$ & 623 \\
\hline Belgium & $56 \%$ & $31 \%$ & $11 \%$ & $2 \%$ & $100 \%$ & 757 \\
\hline France & $55 \%$ & $33 \%$ & $10 \%$ & $2 \%$ & $100 \%$ & 672 \\
\hline Germany & $53 \%$ & $32 \%$ & $14 \%$ & $1 \%$ & $100 \%$ & 1,287 \\
\hline Denmark & $63 \%$ & $24 \%$ & $13 \%$ & $1 \%$ & $100 \%$ & 729 \\
\hline Finland & $61 \%$ & $32 \%$ & $5 \%$ & $2 \%$ & $100 \%$ & 810 \\
\hline Sweden & $69 \%$ & $23 \%$ & $7 \%$ & $1 \%$ & $100 \%$ & 636 \\
\hline Norway & $64 \%$ & $30 \%$ & $5 \%$ & $1 \%$ & $100 \%$ & 770 \\
\hline Estonia & $44 \%$ & $37 \%$ & $17 \%$ & $2 \%$ & $100 \%$ & 672 \\
\hline Greece & $35 \%$ & $56 \%$ & $8 \%$ & $1 \%$ & $100 \%$ & 980 \\
\hline Hungary & $52 \%$ & $38 \%$ & $8 \%$ & $2 \%$ & $100 \%$ & 630 \\
\hline Spain & $46 \%$ & $43 \%$ & $8 \%$ & $3 \%$ & $100 \%$ & 835 \\
\hline Slovenia & $52 \%$ & $40 \%$ & $6 \%$ & $2 \%$ & $100 \%$ & 540 \\
\hline Ireland & $37 \%$ & $47 \%$ & $12 \%$ & $4 \%$ & $100 \%$ & 950 \\
\hline ALL & $52 \%$ & $34 \%$ & $11 \%$ & $2 \%$ & $100 \%$ & 12,516 \\
\hline
\end{tabular}

Notes: Own analysis of the European Social Survey, Round 5. Results are weighted. For definition of underemployment and overemployment see Table A2. 
Table A4: Sample description, by country

\begin{tabular}{|c|c|c|c|c|c|c|c|c|c|}
\hline & $\begin{array}{l}\text { Mean age } \\
\text { woman }\end{array}$ & $\begin{array}{l}\text { Mean age } \\
\text { man }\end{array}$ & $\begin{array}{c}\% \text { low } \\
\text { educated } \\
\text { women }\end{array}$ & $\begin{array}{c}\% \text { medium } \\
\text { educated } \\
\text { women }\end{array}$ & $\begin{array}{l}\% \text { high } \\
\text { educated } \\
\text { women }\end{array}$ & $\begin{array}{c}\% \text { low } \\
\text { educated } \\
\text { men }\end{array}$ & $\begin{array}{c}\% \text { medium } \\
\text { educated } \\
\text { men }\end{array}$ & $\begin{array}{c}\% \text { high } \\
\text { educated } \\
\text { men }\end{array}$ & $\mathbf{N}$ \\
\hline Great Britain & 42.2 & 44.0 & 28.4 & 24.6 & 47.0 & 29.1 & 28.5 & 42.4 & 736 \\
\hline Netherlands & 43.1 & 45.7 & 36.1 & 25.7 & 38.2 & 34.3 & 24.8 & 40.9 & 762 \\
\hline Switzerland & 43.2 & 45.7 & 21.0 & 48.2 & 30.8 & 10.4 & 41.4 & 48.2 & 604 \\
\hline Belgium & 43.1 & 45.5 & 19.3 & 29.0 & 51.7 & 16.9 & 31.3 & 51.8 & 735 \\
\hline France & 42.7 & 45.1 & 15.4 & 45.2 & 39.4 & 14.0 & 54.9 & 31.1 & 650 \\
\hline Germany & 44.1 & 46.7 & 10.0 & 53.4 & 36.6 & 7.2 & 49.9 & 42.9 & 1,264 \\
\hline Denmark & 44.5 & 46.5 & 19.6 & 30.2 & 50.2 & 16.4 & 39.9 & 43.7 & 719 \\
\hline Finland & 42.7 & 44.8 & 12.4 & 31.4 & 56.2 & 14.0 & 39.1 & 47.0 & 788 \\
\hline Sweden & 42.4 & 44.6 & 7.4 & 38.9 & 53.7 & 9.8 & 39.6 & 50.6 & 622 \\
\hline Norway & 42.4 & 45.0 & 10.4 & 32.2 & 57.4 & 9.2 & 40.3 & 50.5 & 760 \\
\hline Estonia & 42.3 & 44.4 & 10.1 & 32.9 & 57.0 & 10.1 & 43.9 & 46.0 & 656 \\
\hline Greece & 41.3 & 45.1 & 29.7 & 43.7 & 26.7 & 31.4 & 42.1 & 26.6 & 968 \\
\hline Hungary & 41.9 & 44.9 & 17.1 & 57.1 & 25.8 & 11.8 & 63.4 & 24.8 & 620 \\
\hline Spain & 42.8 & 45.2 & 53.2 & 14.2 & 32.7 & 51.1 & 13.4 & 35.5 & 805 \\
\hline Slovenia & 44.1 & 46.8 & 16.3 & 50.0 & 33.7 & 11.7 & 64.9 & 23.4 & 522 \\
\hline Ireland & 42.1 & 44.1 & 25.1 & 29.8 & 45.1 & 30.9 & 23.3 & 45.7 & 892 \\
\hline \multirow[t]{2}{*}{ ALL } & 42.8 & 45.3 & 21.0 & 36.6 & 42.4 & 19.8 & 39.3 & 40.9 & 12,103 \\
\hline & $\begin{array}{c}\% \text { child- } \\
\text { less }\end{array}$ & $\%$ age $<6$ & $\begin{array}{c}\% \text { age } \\
6<12\end{array}$ & $\begin{array}{l}\% \text { age } \\
12<18 \\
\end{array}$ & $\%$ age $18+$ & $\%$ rural & $\begin{array}{c}\% \text { small } \\
\text { town }\end{array}$ & $\begin{array}{c}\% \text { big } \\
\text { city }\end{array}$ & \\
\hline Great Britain & 40.9 & 27.2 & 12.8 & 9.4 & 9.8 & 28.7 & 46.3 & 25.0 & 736 \\
\hline Netherlands & 43.2 & 22.3 & 15.5 & 10.0 & 9.1 & 28.4 & 26.0 & 45.7 & 762 \\
\hline Switzerland & 34.3 & 23.2 & 13.3 & 13.7 & 15.6 & 16.9 & 23.8 & 59.3 & 604 \\
\hline Belgium & 34.7 & 23.8 & 13.2 & 12.0 & 16.3 & 23.1 & 22.5 & 54.4 & 735 \\
\hline France & 39.1 & 25.5 & 15.2 & 9.5 & 10.6 & 26.9 & 21.9 & 51.2 & 650 \\
\hline Germany & 45.3 & 18.3 & 11.5 & 12.5 & 12.5 & 19.9 & 37.3 & 42.7 & 1,264 \\
\hline Denmark & 39.2 & 19.1 & 17.4 & 15.4 & 8.9 & 36.3 & 36.6 & 27.1 & 719 \\
\hline Finland & 44.3 & 25.6 & 9.4 & 12.9 & 7.7 & 28.8 & 29.2 & 42.0 & 788 \\
\hline Sweden & 42.0 & 24.3 & 12.5 & 12.2 & 9.0 & 34.7 & 31.7 & 33.6 & 622 \\
\hline Norway & 38.0 & 27.1 & 13.3 & 14.2 & 7.4 & 29.3 & 26.2 & 44.5 & 760 \\
\hline Estonia & 31.7 & 25.9 & 13.0 & 11.3 & 18.1 & 31.1 & 31.6 & 37.4 & 656 \\
\hline Greece & 28.7 & 22.0 & 17.1 & 14.2 & 18.1 & 55.7 & 14.2 & 30.2 & 968 \\
\hline Hungary & 29.8 & 22.1 & 16.0 & 11.1 & 21.0 & 29.2 & 35.5 & 35.3 & 620 \\
\hline Spain & 28.8 & 22.6 & 16.7 & 11.7 & 20.3 & 26.2 & 30.1 & 43.7 & 805 \\
\hline Slovenia & 19.5 & 18.6 & 14.2 & 15.5 & 32.2 & 26.1 & 19.0 & 55.0 & 522 \\
\hline Ireland & 37.3 & 29.2 & 13.8 & 8.3 & 11.4 & 30.2 & 24.9 & 45.0 & 892 \\
\hline ALL & 36.7 & 23.4 & 14.0 & 12.1 & 13.9 & 29.7 & 28.7 & 41.6 & 12,103 \\
\hline
\end{tabular}

Sample restricted to cases without missing values on all predictors, corresponding to the sample of analysis used for regression analysis in Table 3. Values not weighted. 